Pacific Journal of Mathematics

CORRECTION TO: "SPINOR NORMS OF LOCAL INTEGRAL 


\title{
ERRATA
}

Correction to

\section{SPINOR NORMS OF LOCAL INTEGRAL ROTATIONS, II}

\author{
A. G. EARNEST AND J. S. HSIA
}

Volume 61 (1975), 71-86

One consequence of the 2-adic spinor norm calculations in $[\mathbf{3}]$ is an improvement of a theorem of Kneser [5; Satz 5] giving bounds on the power of two dividing the reduced discriminant of an indefinite quadratic Z-lattice having class number exceeding one (see also $[\mathbf{6} ;$ p. 111] for a weaker version, and $[\mathbf{2}$; Thm. 1.3, Chap. 11] for a restatement of Kneser's theorem).

Contrary to the claim made in [3], the bounds obtained in Theorem 4.2 of that paper are not best possible. The example $L \cong\left\langle-7,2^{2}, 2^{4}, \ldots, 2^{2(n-1)}\right\rangle$ (see Remark 4.5) which purports to demonstrate that bounds attained are best possible in fact has class number one, not two as claimed. This can be seen by observing that $\theta\left(O^{+}\left(L_{2}\right)\right) \supseteq \dot{\mathbf{Q}}_{2}^{2} \cup 5 \dot{\mathbf{Q}}_{2}^{2}$ (by Proposition 1.8) and applying the argument in the last paragraph of Lemma 4.3.

We became aware of this error in reading a preliminary draft of Brzezinski's paper [1] , where a bound better than that appearing in our Theorem 4.2 is obtained for a special class of indefinite ternary quadratic Z-lattices. In fact, the methods of our paper apply directly to yield this improved bound for all indefinite ternary $\mathbf{Z}$-lattices.

Lemma 4.4 and, consequently, Theorem 4.2 of [3] can be improved to produce the correct best possible bounds for all ranks. The appropriate strengthened version of that lemma is:

Lemma $4.4^{\prime}$. Let $L$ be as in $\left[3 ;\right.$ Thm. 4.2]. If $s_{p}<n(n-1) / 2$ whenever $p$ is odd and if $h^{+}(L) \neq 1$, then $s_{2} \geq b_{2}^{\prime}$, where

$$
b_{2}^{\prime}= \begin{cases}(3 n-2)(n-1) / 2 & \text { if } n \text { is odd } \\ n(3 n-5) / 2 & \text { if } n \text { is even. }\end{cases}
$$

Proof. As in the proof of Lemma 4.4,

$$
2^{-k} L \cong\left\langle\varepsilon_{1}, 2^{r_{2}} \varepsilon_{2}, \ldots, 2^{r_{n}} \varepsilon_{n}\right\rangle,
$$

$0<r_{2}<\cdots<r_{n}$. It suffices to verify that $r_{3} \geq 6, r_{n} \geq 3 n-3$ for $n>3$ odd, and $r_{n} \geq 3 n-5$ for $n>2$ even. Note first that if $r_{s}-r_{t}=4$ for any $s, t$, then $\theta\left(O^{+}\left(L_{2}\right)\right) \supseteq \dot{\mathbf{Q}}_{2}^{2} \cup 5 \dot{\mathbf{Q}}_{2}^{2}$ (by Proposition 1.8) and $h^{+}(L)=1$ follows as in the proof of Lemma 4.3. From this fact and Theorem 2.2, it can be seen that $r_{2} \geq 1$ implies that $r_{3} \geq 6$ under our assumption that $h(L) \neq 1$. Assume the above inequalities on $r_{j}, j=1,2, \ldots, k$. If $k+1$ is even and greater than 4 , then $r_{k+1} \geq r_{k}+1 \geq(3 k-3)+1=3 k-2=3(k+1)-5$ as desired 
$\left(r_{4} \geq 7\right.$ holds since $\left.r_{3} \geq 6\right)$. If $k+1$ is odd, then, arguing as for $r_{3}$ above, $r_{k+1} \geq(3 k-5)+5=3(k+1)-3$.

Theorem 4.2 remains valid with the values of $b_{2}^{\prime}$ given as above. Moreover, the examples $L \cong\left\langle 1,-2^{6}, 2^{7}\right\rangle, L \cong\left\langle 1,-2^{6}, 2^{7}, \ldots, 2^{3 n-3}\right\rangle$ if $n$ is odd, $n \geq 5$, and $L \cong\left\langle 1,-2^{6}, 2^{7}, \ldots,-2^{3 n-5}\right\rangle$ if $n$ is even, $n \geq 4$, show that the new bounds $b_{2}^{\prime}$ are best possible for all $n \geq 3$. For small values of $n$, the last column of Table 4.8 should show the best possible bounds $b_{2}^{\prime}$ to be $7,14,26,39,57,76,100$ and 125 for $n=3, \ldots, 10$, respectively. The bounds shown for $b_{2}^{\prime \prime}$ in the third column of that table are indeed best possible (note that the final exponent in the example L of Remark 4.7 should read " $4 k$ ", not " $2 k$ ".

Finally, for completeness we note that in Theorem 3.14, (i) should read "If all $2^{r_{2}} L_{i} \ldots$.", (ii) should read "... $2^{r_{\jmath}} L_{j} \ldots 2^{r_{k}} L_{k} \ldots$ ", and the Hilbert symbol appearing in (ivb) should read " $\left(2^{r_{k}-r_{\imath_{0}}} a_{\imath_{0}} \varepsilon_{k}\right.$, $\left.-\operatorname{det} L_{i_{0}}\right)$ ". These modifications were noted in $[4]$.

\section{REFERENCES}

[1] J. Brzezinski, Spinor class groups of orders, J. Algebra, 84 (1983), 468-481.

[2] J. W. S. Cassels, Rational Quadratic Forms, London Mathematical Society monographs, No. 13, Academic Press, 1978.

[3] A. G. Earnest and J. S. Hsia, Spinor norms of local integral rotations, II, Pacific J. Math., 61 (1975), 71-86.

[4] __, Spinor genera under field extensions, II, Amer. J. Math., 100 (1978), 523-538.

[5] M. Kneser, Klassenzahlen indefiniter quadratischer Formen in drei oder mehr Veranderlichen, Arch. Math., 7 (1956), 323-332.

[6] G. L. Watson, Integral Quadratic Forms, Cambridge tracts in mathematics and mathematical physics, No. 51, Cambridge University Press, 1960. 


\title{
PACIFIC JOURNAL OF MATHEMATICS EDITORS
}

\author{
Donald BABBITt (Managing Editor) \\ University of California \\ Los Angeles, CA 90024 \\ J. DugunduI \\ University of Southern California \\ Los Angeles, CA 90089-1113 \\ R. FINN \\ Stanford University \\ Stanford, CA 94305 \\ HermanN FlaschKa \\ University of Arizona \\ Tucson, AŻ 85721
}

C. C. Moore

University of California

Berkeley, CA 94720

ARTHUR Ogus

University of California

Berkeley, CA 94720

Hugo Rossi

University of Utah

Salt Lake City, UT 84112

H. SAMELSON

Stanford University

Stanford, CA 94305

ASSOCIATE EDITORS
R. ARENS
E. F. BECKENBACH
B. H. NEUMANN
F. WOLF
K. YoSHIDA (1906-1982)

\section{SUPPORTING INSTITUTIONS}

$\begin{array}{ll}\text { UNIVERSITY OF ARIZONA } & \text { UNIVERSITY OF OREGON } \\ \text { UNIVERSITY OF BRITISH COLUMBIA } & \text { UNIVERSITY OF SOUTHERN CALIFORNIA } \\ \text { CALIFORNIA INSTITUTE OF TECHNOLOGY } & \text { STANFORD UNIVERSITY } \\ \text { UNIVERSITY OF CALIFORNIA } & \text { UNIVERSITY OF HAWAII } \\ \text { MONTANA STATE UNIVERSITY } & \text { UNIVERSITY OF TOKYO } \\ \text { UNIVERSITY OF NEVADA, RENO } & \text { UNIVERSITY OF UTAH } \\ \text { NEW MEXICO STATE UNIVERSITY } & \text { WASHINGTON STATE UNIVERSITY } \\ \text { OREGON STATE UNIVERSITY } & \text { UNIVERSITY OF WASHINGTON }\end{array}$

The Supporting Institutions listed above contribute to the cost of publication of this Journal, but they are not owners or publishers and have no responsibility for its content or policies.

Mathematical papers intended for publication in the Pacific Journal of Mathematics should be in typed form or offset-reproduced (not dittoed), double spaced with large margins. Please do not use built up fractions in the text of the manuscript. However, you may use them in the displayed equations. Underline Greek letters in red, German in green, and script in blue. The first paragraph must be capable of being used separately as a synopsis of the entire paper. In particular it should contain no bibliographic references. Please propose a heading for the odd numbered pages of less than 35 characters. Manuscripts, in triplicate, may be sent to any one of the editors. Please classify according to the scheme of Math. Reviews, Index to Vol. 39. Supply name and address of author to whom proofs should be sent. All other communications should be addressed to the managing editor, or Elaine Barth, University of California, Los Angeles, California 90024.

There are page-charges associated with articles appearing in the Pacific Journal of Mathematics. These charges are expected to be paid by the author's University, Government Agency or Company. If the author or authors do not have access to such Institutional support these charges are waived. Single authors will receive 50 free reprints; joint authors will receive a total of 100 free reprints. Additional copies may be obtained at cost in multiples of 50 .

The Pacific Journal of Mathematics is issued monthly as of January 1966. Regular subscription rate: $\$ 190.00$ a year (5 Vols., 10 issues). Special rate: $\$ 66.00$ a year to individual members of supporting institutions.

Subscriptions, orders for numbers issued in the last three calendar years, and changes of address should be sent to Pacific Journal of Mathematics, P.O. Box 969, Carmel Valley, CA 93924, U.S.A. Old back numbers obtainable from Kraus Periodicals Co., Route 100, Millwood, NY 10546.

The Pacific Journal of Mathematics at P.O. Box 969, Carmel Valley, CA 93924 (ISSN 0030-8730) publishes 5 volumes per year. Application to mail at Second-class postage rates is pending at Carmel Valley, California, and additional mailing offices. Postmaster: Send address changes to Pacific Journal of Mathematics, P.O. Box 969, Carmel Valley, CA 93924.

PUBLISHED BY PACIFIC JOURNAL OF MATHEMATICS, A NON-PROFIT CORPORATION

Copyright $@ 1984$ by Pacific Journal of Mathematics 


\section{Pacific Journal of Mathematics}

\section{Vol. 115, No. $2 \quad$ October, 1984}

Ersan Akyildiz, Gysin homomorphism and Schubert calculus ...........257

Marilyn Breen, Clear visibility and unions of two starshaped sets in the

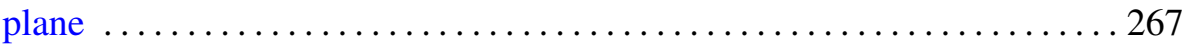

Robert F. Brown, Retraction methods in Nielsen fixed point theory . ......277

Herbert Busemann and Bhalchandra B. Phadke, A general version of Beltrami's theorem in the large ............................... 299

Gerald Arthur Edgar and Robert Francis Wheeler, Topological properties of Banach spaces ............................... 317

Yaakov Friedman and Bernard Russo, Conditional expectation without

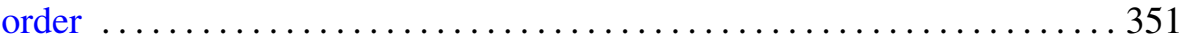

Robert Allen Goggins, Cobordism of manifolds with strong almost tangent

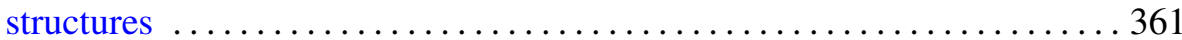

Mike Hoffman, Noncoincidence index of manifolds . . . . . . . . . . . . . 373

William H. Julian, $\varepsilon$-continuity and monotone operations $\ldots \ldots \ldots \ldots 385$

Gerasimos E. Ladas, Y. G. Sficas and I. P. Stavroulakis, Nonoscillatory

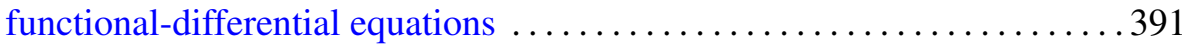

Arnold William Miller and Karel Libor Prikry, When the continuum has

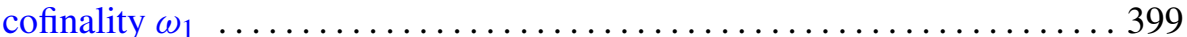

Jean-Leah Mohrherr, Density of a final segment of the truth-table

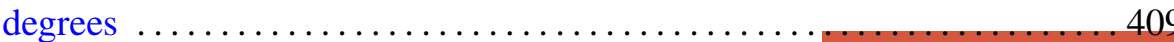

Carl Norman Mutchler, The flat Cauchy problem for radially hyperbolic operators from a characteristic manifold of high codimension ...

Kenji Nakagawa, On the orders of automorphisms of a closed Riemann surface

W. Ricker, Representation of vector-valued functions by Laplace transforms

Jorge Donato Samur, On semigroups of convolution operators in Hilbert

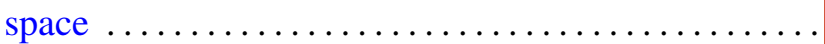

Joseph Gail Stampfli, One-dimensional perturbations of operators 481 Andrew George Earnest and John Sollion Hsia, Correction to: "Spinor norms of local integral rotations. II" 